Proceedings

\title{
Opportunities for Improving Feed Use Efficiency for Sustainable Dairy Production in Pakistan ${ }^{\dagger}$
}

\author{
Muhammad Tariq
}

Citation: Tariq, M. Opportunities for Improving Feed Use Efficiency for Sustainable Dairy Production in Pakistan. Proceedings 2021, 73, 11. https://doi.org/10.3390/IECA2020-08 826

Published: 2 December 2020

Publisher's Note: MDPI stays neutral with regard to jurisdictional claims in published maps and institutional affiliations.

\section{Copyright: (c) 2020 by the authors.} Licensee MDPI, Basel, Switzerland. This article is an open access article distributed under the terms and conditions of the Creative Commons Attribution (CC BY) license (http://creativecommons.org/licenses /by/4.0/).

\author{
Department of Livestock Management, University of Agriculture Faisalabad, Faisalabad 38000, Pakistan; \\ tariqlm@uaf.edu.pk \\ + Presented at the 1st International Electronic Conference on Animals-Global Sustainability and Animals: \\ Science, Ethics and Policy, 5-20 December 2020; Available online: https://ieca2020.sciforum.net/.
}

\begin{abstract}
Buffalo and cattle are main dairy animals of Pakistan, making 30\% of the total livestock. Out of total milk produced in the country, buffalo contributes about $68 \%$, followed by cattle (27\%), rest $(5 \%)$ by sheep, goats, and camels. They are kept both in rural as well as peri-urban dairy production systems. These dairy animals mostly strive on low-quality feed stuffs including roughages and crop-residues with poor nutritive value resulting in poor production and reproduction performance. Recent investigations and published data show that there is also an issue of unjustified feeding without considering the production and physiological stages of dairy animals, resulting in overfeeding of non-productive and under-feeding of productive animals, leading to poor feed use efficiency. There is also no separate feeding system for different classes of dairy animals. Furthermore, in the prevailing dairy production scenario, there is absence of an efficient feeding system especially devised for growing heifers (kept as replacement herd) keeping in view their feeding requirements that could reduce their age at puberty with a significant reduction in the cost of feeding. Similarly, the introduction of milk replacer and early weaning of calves are very effective ways without any adverse effects on growth when given free access to good quality calf starter, and it could add to dairy economics. Fodder scarcity during the winter months (November to January) and summer (May-June) in Pakistan is another big constraint toward sustainable dairying. It is concluded that more efficient feed utilization in these dairy production systems could be achieved by developing innovative approaches and solutions (hay and silage making) to fight these scarcity periods and developments in dairy nutrition, like the establishment of nutrient requirements for dairy animals for local dairy breeds, adopting group feeding practices of dairy animals according to the stage of lactation and production status, and proper feeding systems for growing heifers and effective milk replacer feeding for calves. These practical and innovative steps could effectively lead to sustained dairy production in Pakistan.
\end{abstract}

Keywords: dairy production; feeding management; resource use efficiency; feeding system; nutrition

\section{Introduction}

The dairy sector has seen a major intensification during the past fifty years worldwide, with the increase in scales and efficiency of production driven by the demand from a growing human population and increasing incomes of parts of the population [1,2]. The increase in milk output was achieved through advances in animal nutrition and breeding, feed use efficiency, health management, housing, and automation strategies, along with supporting policies [3]. In Pakistan's peri-urban commercial dairy farms, feed accounts for more than seventy percent of the operational costs $[2,4]$ because animals are stall-fed year-round on wheat straw, purchased green fodder, and concentrate feeds which farmers obtain from the markets. Seasonal variations in quantity and quality of the 
roughage feeds are a major concern to farmers, especially during the scarcity periods [5], and high feed costs negatively affect the profitability of the dairy enterprises. In consequence, inadequate nutrition of dairy animals is considered one of the major limitations to dairy production [6] and may even lead to morbidity and mortality of high milk producers [7]. Low gross margins of milk sales due to the high feed costs often push farmers to unethical practices such as adulteration of milk in order to improve their economic situation $[7,8]$.

In spite of the substantial contribution of livestock to the national economy, per head productivity of dairy animals under present farm conditions is relatively low in Pakistan. Among dairy buffaloes, 98\% are producing less than 10 liters of milk per day [9]. High productive and reproductive efficiency of livestock can only be achieved if animals receive the required quantities of feedstuffs providing all nutrients in the needed proportion [10]. A sound intervention strategy to increase income from dairy animals should focus on two fronts: firstly, lowering feed costs, and secondly, increasing individual animal productivity [4]. Both require adequate nutritional management and high efficiency of feed utilization. Given the paucity of information regarding the nutritional status of lactating animals in Pakistan's commercial and semi-commercial dairy units, specific measures that help dairy farmers adequately address the previous issues are difficult to devise. This article, therefore, discussed the feeding practices for lactating dairy animals in order to identify shortcomings and potential improvements.

\section{Existing Feeding Practices for Dairy Animals}

In commercial and semi-commercial farms, most of the farmers use green fodder crops, wheat straw, and concentrate feeds (mostly industrial by-products: cottonseed cake, maize oil cake, cereal by-products). Usually, green fodder is bought daily from fodder markets; only a few farmers grew their own fodder; wheat straw is also mostly bought on a daily basis from retailers dispersed in town. In general, dairy households chop the green roughages to $2-3 \mathrm{~cm}$ length and mix these with concentrate feeds and finely chopped wheat straw to make a total mixed ration [2].

\section{General Aspect of Dairy Production and Feeding Management}

\subsection{Different Feed Types}

Nutrition is a major factor affecting animal health, milk production, and reproduction, thus the overall productivity of dairy animals. Maize and berseem are the preferred green feeds of commercial and semi-commercial dairy farmers as reported by References $[2,4]$. Wheat straw is an integral part of the basal dairy diet. All lactating animals are daily supplied with a home-mix of concentrates ( $4-5 \mathrm{~kg}$ per animal) without taking into account the individual milk production [11]. The type and quantity of concentrate feed varied within a farm and between farms and depended on season, availability, market price, and financial capacity of the farmer. Therefore, concentrate feeds, being major sources of protein and energy, are often not fed at the required level due to unavailability and high costs [12], especially for small-scale farmers. Furthermore, the quality of concentrate feeds usually not matching that of the roughages since farmers have little or no knowledge of feed quality.

\subsection{Feeding of Lactating Buffalo and Cattle}

The undifferentiating feeding of lactating buffaloes and cattle in a herd is apparently practiced for ease of management and to save labor, but this practice leads to nutrient undersupply in high-yielding animals and to nutrient oversupply in animals at the end of lactation or of low milk production potential. Both phenomena affect the health and reproductive performance of the animals [4]. Apart from not getting enough fodder, the rations are found to be deficient in energy and protein, some only supplying about $50 \%$ of the protein demand of all classes of the dairy animals; conversely, the fiber concentra- 
tion of the rations is found to be higher than the recommended level. Only very few of the dairies are feeding mineral mixtures to their lactating animals [2].

\subsection{Seasonal Impacts on Feeding Management}

Different seasons during a year have a significant effect on the offering of feed resources, on their nutritional value, as well as the availability of different types of green fodders, as shown in Figure 1. According to various sources [13-15], there are two periods of fodder scarcity in Punjab: the peak of winter (December and January) and the hot summer months (June and July). In these scarcity periods, undernourishment and low performance of animals are very likely due to the scarcity of fodder in terms of both quantity and quality. Such scarcity can be overcome by proper feeding management through hay and silage making as shown in Figure 2; the latter is recently receiving increasing attention in Pakistan [16].

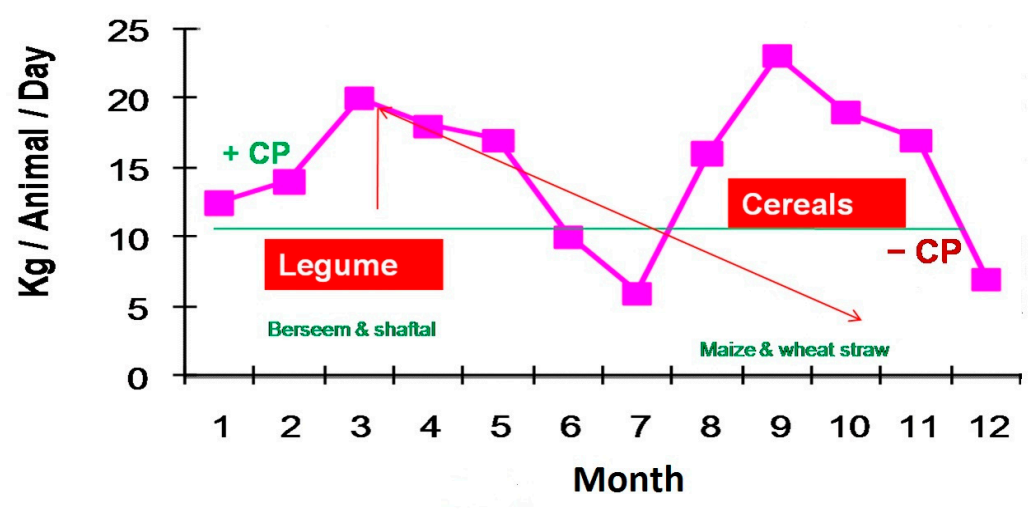

Figure 1. Year-round fodder situation and availability of different fodders during different months of the year [17].

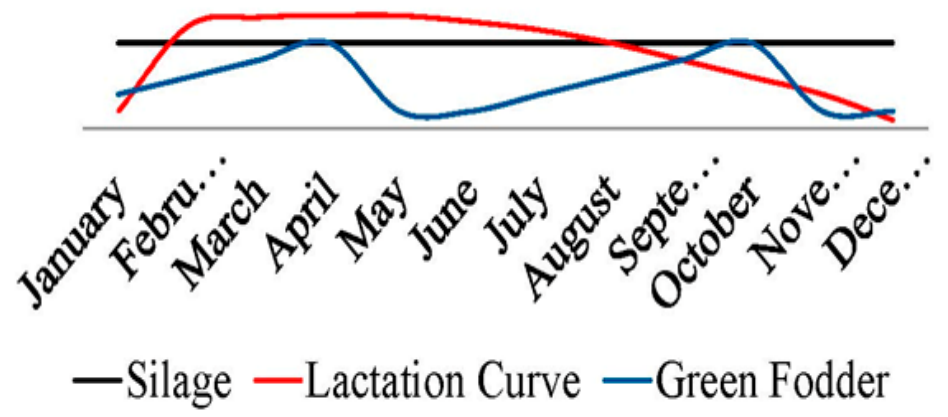

Figure 2. Shows how silage fits in dairy production system [17].

\section{Economic Situation of These Dairy Farms and Management of Available Resources}

Due to differences in the available resources and economic situation of the farms, the average offering of feed dry matter, crude protein, and fibrous fractions (Neutral Detergent Fiber) are significantly different between different production systems (rural, semi-commercial, and commercial) with similar differences of values for dry matter offered. Since mixed crop and livestock farmers also cultivated wheat and fodder crops such as maize, sorghum, and berseem, they have access to good quality roughages and wheat straw in sufficient quantities and at low cost. Although this was not the case for the (mostly) landless semi-commercial and commercial farmers, the latter disposed of sufficient money and bargaining power (economies of scales effect of these comparatively large and fully commercial dairy units) to purchase high amounts of feed at re- 
duced prices on the fodder markets [2]. The published studies show that the total number of animals per dairy herd, and of lactating animals, respectively, was negatively correlated with the offered amount of green fodder and positively correlated with the offered amount of concentrates [18].

In another study previously conducted by the author, it was observed that from the amounts of feed offered daily, about $90 \%$ is consumed and $10 \%$ is lost through leftovers and spillage [2]. Since group feeding of lactating buffaloes and cattle ignores species, stage of lactation, and milk yield, the calculational approach assumes that each animal in a herd consumes the same amount of feed; this is undoubtedly an incorrect assumption that cannot be adjusted for here. The findings of other studies on small-scale dairy production in Pakistan [2] and India [19] show that in these dairy systems buffaloes (major dairy animals) are always more deficient in energy and supply of total digestible nutrients than cattle.

The trend towards energetically oversupplying cattle and undersupplying buffaloes may be explained by the fact that cattle are kept for their higher milk yields when ignoring milk fat content. By mixing cattle with buffalo milk, farmers are able to sell a higher total volume of milk without the need to adulterate the product, thus receiving higher total revenue for their daily production without having to fear sanctions from their middlemen or clients.

\section{Conclusions}

It is concluded that more efficient feed utilization in these dairy production systems could be achieved by developing innovative approaches and solutions (hay and silage making) to fight these scarcity periods and developments in dairy nutrition, like the establishment of nutrient requirements for dairy animals for local dairy breeds, adopting group feeding practices of dairy animals according to the stage of lactation and production status, and proper feeding systems for growing heifers and effective milk replacer feeding for calves. These practical and innovative steps could effectively lead to sustained dairy production in Pakistan.

Funding: The author is thankful to the urban and peri-urban farmers of Faisalabad for their willingness to participate in this study. The first author received a scholarship from Higher Education Commission of Pakistan, Islamabad for completion of his PhD project.

\section{Institutional Review Board Statement: N/A.}

Informed Consent Statement: N/A.

Data Availability Statement: The data presented in this study are available in the PhD thesis of the author (https://cuvillier.de/uploads/preview/public_file/8228/Leseprobe.pdf).

Conflicts of Interest: The author declares there is no conflict of interest with any person or institution for this study.

\section{References}

1. FAO. Dairy Development in Pakistan; Food and Agriculture Organization of the United Nations: Rome, Italy, 2011.

2. Tariq, M. Opportunities for Improving Resource Use Efficiency in Peri-Urban Dairy Herds in Faisalabad, Punjab, Pakistan. Ph.D. Thesis, University of Kassel Germany, Kassel, Germany, September 2013.

3. FAO. Dairy Development in Argentina; Food and Agriculture Organization of the United Nations: Rome, Italy, 2011.

4. Habib, G.; Hameed, A.; Akmal, M. Current feeding management of peri-urban dairy buffaloes and scope for improvement. Pak. Vet. J. 2007, 27, 35-41.

5. Gillah, K.A.; Kifaro, G.C.; Madsen, J. Urban and peri urban dairy farming in East Africa: A review on production levels, constraints and opportunities. Livest. Res. Rural Dev. 2012, 24, 198. Available online: http://www.lrrd.org/lrrd24/11/gill24198.htm (accessed on 10 March 2021).

6. Olafadehan, O.A. Potentials for Improving Dairy Cattle Production in the Agro-Pastoral Farming System in the Derived Savanna of Oyo State, Nigeria. Ph.D. Thesis, Department of Animal Science, University of Ibadan, Ibadan, Nigeria, 2007.

7. Jalil, H.; Rehman, H.U.; Maqbool, H.S.; Hussain, S.S. Analysis of milk production system in peri-urban areas of Lahore (Pakistan): A case study.Pak. Econ. Soc. Rev. 2009, 47, 229-242. 
8. Garcia, O.; Mahmood, K.; Hemme, T. A Review of Milk Production in Pakistan with Particular Emphasis on Small Scale Producers; Pro-Poor Livestock Policy Initiative Working Paper No. 3; FAO: Rome, Italy, 2003.

9. Khan, R.; Qureshi, M.S.; Mushtaq, A.; Ghufranullah Naveed, A. Effect of quality and frequency of drinking water on productivity and fertility of dairy buffaloes. J. Anim. Plant Sci. 2012, 22, 96-101.

10. NRC. Nutrient Requirements of Dairy Animals, 7th ed.; National Research Council, National Academy Press: Washington, DC, USA, 2001.

11. Khan, U.; Lund, J.; Javaid, S.; Ul-Hasan, Z. Economic analysis of milk production indifferent cattle colonies of Karachi. Pak. J. Agric. Sci. 2008, 45, 403-409.

12. Nouala, F.S.; Akinbamijo, O.O.; Adewumi, A.; Hoffmann, E.; Muetzel, S.; Becker, K. The influence of Moringaoleifera leaves as substitute to conventional concentrate on the in vitro gas production and digestibility of groundnut hay. Livest. Res. Rural Dev. 2006, 18, 121. Available online: http://www.lrrd.org/lrrd18/9/noua18121.htm (accessed on 30 November 2020).

13. Teufel, N.; Gall, C.F. Characteristics of village milk production in the Punjab of Pakistan. In Sustainable Technology Development in Animal Agriculture; Deutscher Tropentag: Berlin, Germany, $1999 . \quad$ Available online: http://ftp.gwdg.de/pub/tropentag/proceedings/1999/referate/STD_A3.pdf (accessed on 30 November 2020).

14. Afzal, M.; Anwar, M.; Mirza, M.A. Some factors affecting milk yield and lactation length in Nili Ravi buffaloes. Pak. Vet. J. 2007, 27, 113-117.

15. Ali, T. Pakistan: A Case Study of Milk Production and Marketing by Small and Medium Scale Contract Farmers; Haleeb Foods Ltd., Sustainable Markets Group, International Institute for Environment and Development (IIED): London, UK, 2007.

16. Teufel, N. International Livestock Research Institute (ILRI), Nairobi 00100, Kenya. Personal Communication, May 2013.

17. Akmal, M. Scope \&opportunities of green fodder for dairy development. In Proceedings of the International Dairy Conference on Future Prospects of Dairy Production in Pakistan held in University of Agriculture, Faisalabad, Pakistan, 3-4 November 2008.

18. Hagmann, J. Opportunities and Constraints of Peri-Urban Buffalo and Dairy Cattle Systems in Faisalabad, Punjab, Pakistan; ICDD Working Paper No (2); University of Kassel: Kassel, Germany, $2010 . \quad$ Available online:http://www.uni-kassel.de/einrichtungen/fileadmin/datas/einrichtungen/icdd/Publications/ICDD_Working_Paper_No.2 _Hagmann.pdf (accessed on 10 March 2021).

19. Singh, V.K.; Singh, P.; Verma, A.K.; Mehra, U.R. On farm assessment of nutritional status of lactating cattle and buffaloes in urban, peri-urban and rural areas of Middle Gangetic Plains. Livest. Res. Rural Dev. 2008, 20, 130. Available online: http://www.lrrd.org/lrrd20/8/singh20130.htm (accessed on 30 November 2020). 